\title{
The Volunteerism Actualization of the Young Generation During the Covid-19 Pandemic
}

\author{
Risti Nur Rohmawati ${ }^{1, *}$, Idrus Affandi ${ }^{2}$, Leni Anggraeni ${ }^{3}$
}

\author{
1,2,3 Universitas Pendidikan Indonesia, Bandung, Indonesia \\ *Corresponding Authors. Email: ristinur30@upi.edu
}

\begin{abstract}
The increase in Covid-19 cases in Indonesia is at a very worrying level. Seen from the booming number of Covid-19 patients in various hospitals. Covid-19 is a common problem that must be immediately resolved, therefore the participation of all elements is needed, not only the regional central government but also the community must play an active role. The role of the younger generation is very much needed during this pandemic. This study aims to determine and analyze the form of volunteerism of the younger generation during the covid-19 pandemic. This research conducted through a qualitative approach with a literature study method, focused data analysis: data reduction, displaying verification data or drawing conclusions. The result of the research is that the younger generation has the opportunity to create a supportive environment in a health emergency. The younger generation is a potential resource and group of citizens with various influences, and will encourage the implementation of various effective policies to ensure the control of Covid-19 throughout Indonesia. The younger generation has advantages that generally lead to the nature of creativity, proficient in using technology. The role of the younger generation as agents of change, agents of social control and agents of moral strength provides strength in society to come together to rise up against this pandemic. Volunteering in civic engagement as a driving force and development to create citizens who have high discipline, responsibility, have strong independence and national values based on the spirit of social care, sincerity, volunteerism and also togetherness as a nation and state.
\end{abstract}

Keywords: Civic engagement, Covid-19 pandemic, The younger generation, Volunteerism.

\section{INTRODUCTION}

It's been a year since the Covid-19 pandemic has hit the whole world. Not only in the health sector, but also in the economic, social and educational fields. Therefore, several countries have implemented various policies, one of which is imposing a lockdown in an effort to stop the spread of the Covid-19 virus. Not a few people who lost their jobs, whose businesses went bankrupt and also difficult to get a job. All levels of society are feeling the impact of this pandemic.

The first time Covid 19 was detected in Wuhan, Central Hubei, China. More than 200 cases were identified and 3 deaths were reported [1]. Initially, the virus was thought to have been caused by exposure to the Huanan seafood wholesale market, which sells many species of live animals. Common symptoms of Covid 19 are breathing problems, fever and lung infiltration [2]. The emergence of Covid 19 has attracted global attention, and On January $30 \mathrm{WHO}$ has declared COVID-19 a public health emergency of international concern [3].
Every day the number of cases is increasing, and the government continues to make various policies for recovery in various fields. Currently, the increase in Covid-19 cases in Indonesia is at a very worrying level. It can be seen from the booming number of Covid-19 patients in various hospitals. The number of cases in Indonesia continues to increase rapidly, until June 2020 as many as 31,186 confirmed cases and 1851 cases died. The highest cases occurred in DKI Jakarta Province with 7,623 confirmed cases and 523 (6.9\%) deaths [4]. This is a challenge for all of us, not only the government's job, but all elements must be involved in breaking the chain of the spread of Covid-19. In Indonesia, the awareness of the public is still low to follow various government advice, this can be seen from the habits of the people who still ignore health protocols and there are still many community activities outside the home [5].

Currently Covid 19 is a common problem that must be immediately found a solution, therefore the participation of all elements is needed, not only the regional central government but also the community 
must take an active role. The hope to realize the ideals of society in social life is the involvement of its citizens.

Citizen engagement is a process by which a person believes that he or she must and can make a difference in improving his or her community. The process to increase these differences is that a person needs the knowledge, values, skills needed through attitudes and behavior [6]. As a citizen, you will never be separated from the life of your country, you will always interact and be responsible for your country [7].

A citizen must have social sensitivity to various problems that exist in community life, supported by having a high commitment and trying to make it happen in various aspects of the life of the state and nation. The involvement of citizens is very much needed at this time as a real action in life in society. The participation of citizens is emphasized in service to the local community voluntarily, either acting independently by individuals or as participants in a group [8]. Community engagement is often referred to as volunteerism, a commitment that encourages citizens to participate in the life of their community and the larger society. Every citizen must have a sense of responsibility, especially to morals in the environment and participate in their environment.

The role of the younger generation is needed at this time. The younger generation is a potential resource and group of citizens with various influences, and will encourage the implementation of various effective policies to ensure the control of Covid-19 throughout Indonesia. The younger generation is different from other generations. The younger generation has advantages that generally lead to the nature of creativity, proficient in using technology, idealism. Young people have the opportunity to create a supportive environment in a health emergency. The younger generation as agents of change, as social control and as a moral force [9]. Young people have the ability and opportunity to create an environment and adapt to any situation. The younger generation has the resilience, speed, wisdom and network to innovate technology-based, making it easier for people to use the term "new normal" to socialize the new lifestyle.

The awareness and volunteerism of the younger generation to carry out their responsibilities during the Covid-19 pandemic can in fact be done with various concepts. One of them is by volunteering as a form of social responsibility. For developing countries, voluntary services can be an advantage because developing country governments are still far from good in terms of social conditions. The potential for volunteerism in urban areas is very large because urban communities have special skills that can contribute to the realization of the goals of a community-based organization.

This study aims to determine and analyze how volunteerism of the younger generation is during the Covid-19 pandemic.

\section{LITERATURE REVIEW}

\subsection{Civic education}

Citizenship Education is one way to become a good citizen, Pancasila education is based on morals and is the capital to provide basic education about Pancasila, education based on defending the country where citizens can be useful for the nation [10].

Civic education is an education that is important to be learned by all levels from elementary to high. Citizenship Education in some countries is known by several terms. The terms of Citizenship Education are Civic education, citizenship educations, and democracy educations [11].

In an international study conducted with the School Curriculum and Assessment Authority (SCAA) through the "National Foundation For Educational Research in England and Wales (NFER)", operationally defines the term "citizenship education" as:

Citizenship or civics education is construed broadly to encompass the prepation of young people for their roles and responsibilities as citizens and, in particular, the role of education (through schooling, teaching, and learning) in that preparatory Process).

That is, civic education has been developed and broadly formulated to enable young people to play an active and responsible role, play a special role in education, teaching, school education and the preparation of these citizens [12].

Citizenship is an adaptation of various disciplines chosen and adapted from the social sciences, humanities, citizenship and basic human activities. These disciplines are structured and proposed from the perspective of psychology and science to realize social research education. One of its goals [13].

It means that civic education is part of the social family which discusses the science of citizenship in general, civic culture, socio-cultural activities of citizenship, and also covers all aspects of life to prepare citizens who can know their roles and responsibilities in society. Citizenship education is very important to be conveyed and also understood by every citizen. In addition to containing the things above, civic education also explains the rights and obligations of citizens, elements of the state, democracy, politics, rights, and the law. In addition, citizens will be taught how to become intelligent citizens in knowledge, emotions, and life skills.

\subsection{Civic Engagement}

Civic engagement is a concept that is still underresearched in the world of education, especially Citizenship Education. Civic engagement has many meanings and meanings, where civic engagement can be defined depending on the interests or needs of the 
maker. The interests of civic engagement include community service, collective action, political involvement, and social change.

Civic Engagement is closely related to political engagement, the problem that arises from political engagement is the lack of citizen involvement in terms of democracy. From this statement, it is clear that Civic Engagement has a relationship with political engagement, in which case political engagement is a follow-up to Civic Engagement. Civic Engagement as

Civic engagement, where someone works to make a difference in their life to develop skills, knowledge, values, and motivation to make that difference. This means that it can indirectly improve the quality in a community, either in a political or non-political process [14].

Citizen involvement, working to make a difference in their lives to develop all their potential in the form of values, skills, knowledge, and motivation to make that difference. This means that it can indirectly improve the quality of a society, both in the political and nonpolitical processes. In this definition Civic Engagement is defined broadly, in which case Civic Engagement is a combination of knowledge, skills, values and motivation. Civic Engagement is not merely an activity carried out by individuals or community groups, but a combination of the things that have been mentioned previously.

Citizens must be involved in various activities of their nation and state and are required to participate". In fact, good citizens will definitely play an active role in the life of community government so that citizen participation in society can be achieved.

Participation is one of the main concepts of citizen participation in social life. Participation means that a person believes that he or she must and can make a difference in improving the environment and community. Involvement between citizens and their country.

If there is a greater sense of responsibility to move and act with gusto on its commitment to educating citizens who are involved throughout their lives, little but conclusive research has been previously summarized, and the inclusion of arts-related practices in civic engagement in education is lacking [15].

From these statements it can be concluded that there is a greater sense of responsibility to move and act passionately on its commitment to educating engaged citizens for life, the scanty but conclusive research summarized earlier, and the lack of inclusion of artsrelated practices in community engagement in education

\subsection{Civic Engagement in Citizenship Education}

Civic education basically has two meanings, namely narrow and broad. Civic education in a narrow sense is also known as civic education. Citizenship education is a subject studied in schools that aims to equip students with a civic foundation so that they can become good citizens and play an active role in social life.

Broadly speaking, civic education refers to the participation and participation of citizens in social issues [16]. This is close to the terminology used by Hoskins, namely active citizenship which is defined as "participation in civil society, community and or political life, charactericed by mutual respect and nonviolence and in accordance with human right and democracy" [17].

From the explanation above, an active citizen means a citizen who wants to take part in the process of administering the government, is not apathetic and upholds human rights in the implementation of the democratic process. In connection with this understanding, it can be understood that an active citizen is not someone who is apathetic or does not want to contribute to the process of administering government, but someone who wants to take part in the process of administering government, for example by participating in democratic activities.

\subsection{Volunteering}

Volunteering is the act of helping others. When individuals feel there is a problem that drives them to struggle or take action, they will seek to act according to their ideology as a space for their own struggle, and based on a sense of volunteer service, they will find motivation for activism. The actions that these people take are based on the need and awareness of connectivity. In essence, voluntary service is a complex social phenomenon that involves patterns of social relations and interactions of individuals, groups, associations, or organizations.

Voluntarism is voluntary action in the public interest. The essence of voluntarism departs from the value of sincerity and social generosity, which is a voluntary action aimed at the public interest or improvement of the human condition. Generosity as a moral effort to liberate human beings from all their problems is not based on personal interests, but arises by itself.

"volunteerism also focused on aspects of helping another without material rewards, but emphasized the helper's free will'.

This means that volunteerism focuses on providing assistance without expecting material rewards, but emphasizes the free will of the helper.

\section{METHOD}

This research was conducted using a qualitative approach with a literature study method. This study aims to identify and analyze the form of youth volunteerism during the COVID-19 pandemic. Focused 
data analysis: data reduction, presentation of verification data or drawing conclusions. Qualitative approach is part of educational research in which the researcher on the views of research participants, asks general and broad questions, collects data that consists mostly of words or text from research participants, explains the data obtained, and conducts subjective and biased investigations [18].

\section{RESULT AND DISCUSSION}

In the condition of the Covid-19 pandemic which is getting more massive in Indonesia. The government continues to do various things to reduce the rate of this pandemic. All elements are responsible for the Covid19 pandemic to end quickly. One important component is the cooperation between the government and the community. The younger generation is the next generation of the nation, and it will bring change for the progress of the country.

The younger generation has the ability and opportunity to create an environment and adapt to any situation. The younger generation has the resilience, speed, wisdom and network to innovate technologybased. The younger generation has a native digital character, it is proper for the younger generation to be at the forefront in the midst of society and play an active role as a driving force in echoing health protocols.

Volunteering of the younger generation during the pandemic is very much needed. The younger generation is part of the state as agents of change and agents of social control. A change agent has the task of assisting the community in planning a development, planning actions to improve the existing situation, focusing on problems, organizing assistance, overcoming difficulties, and evaluating the results of planned efforts [19].

Furthermore, an agent of change must also have an important function in the social life of the community. That is:

1) Catalyst (liaison), namely an agent of change is expected to be a driver in the community as a form of change action.

2) Solution giver (providing a solution), which must be able to provide solutions or input as a form of solving various problems that occur in the community.

3) Process helper (providing help), namely an individual who must always be ready to help in the process of change in society.

4) Resources linker (sources), namely, being a liaison with various sources needed in order to solve problems that occur [20].

Meanwhile, as an agent of social control, it is a process that is good and planned or unplanned and has the aim of inviting, guiding and forcing the public to be willing to comply with various applicable values and rules. The purpose of social control is as a form of supervision so that people's lives are in accordance with mutually agreed rules and patterns [21].

The initiatives from the younger generation to prevent the spread of Covid-19 that can be done are:

1) Conduct regional quarantine by closing the residential portal door. This is intended so that people from outside the area who are not interested do not enter carelessly who are feared to carry the virus.

2) Carry out health protocols, namely by using masks, washing hands, disinfectants, maintaining distance. This is intended so that we become an example for the surrounding community who still ignore health protocols.

3) Making and distributing masks, hand sanitizers for free to the public

4) Doing fundraising for people in need

5) Educating the public door to door or through digital media regarding the importance of clean living [22].

The form of participation that does not have to be in the form of material only, in the form of non material can also be done. Humanitarian activities carried out in good faith can build mutual respect between individuals and society. The main purpose of volunteer service is to be able to solve social problems and develop human resources. In this kind of work, when the individual as a person is motivated by values, he can embody the spirit of voluntary service, even his behavior exceeds the role of the bureaucracy.

In the perspective of civic engagement, the involvement of the younger generation is as civic engagement as community service, namely a person's obligation to actively participate either individually or together in performing voluntary services that will strengthen the local community. Then civic engagement as social change, namely participating in people's lives to make social change.

Civic engagement is a concept that is still underresearched in the world of education, especially civic education. The definition of civic engagement depends on the interests of the makers of the definition. Civic engagement can be divided into two, namely structural and everyday. Volunteering of the younger generation in people's lives is included in civic engagement which is daily. The involvement of all elements of society is one of the determining factors for the success of various government policies. Civic engagement has an important role in supporting every program or government policy in breaking the chain of the spread of Covid-19.

\section{CONCLUSION}

The Covid-19 case in Indonesia is at a very worrying level. It can be seen from the booming number of Covid-19 patients in various hospitals. This is a challenge for all of us, not only the government's 
job, but all elements must be involved in breaking the chain of the spread of Covid-19. In Indonesia, public awareness is still low to follow various government advice, this can be seen from the habits of people who still ignore health protocols and there are still many community activities outside the home.

The younger generation is a potential resource and group of citizens with various influences, and will encourage the implementation of various effective policies to ensure the control of Covid-19 throughout Indonesia. The younger generation is different from other generations. The younger generation has advantages that generally lead to the nature of creativity, proficient in using technology, idealism.

The form of participation that does not have to be in the form of material only, in the form of non material can also be done. Civic engagement is becoming a rare item nowadays because of the nature of society which is starting to be individual. The younger generation as agents of change, agents of social control and agents of moral power become strong capital to change people's lives for the better. Volunteering from the younger generation during the Covid-19 pandemic is by actively carrying out health protocols, educating the public about the dangers of Covid 19, distributing masks and hand sanitizers and so on.

\section{AUTHORS' CONTRIBUTIONS}

The author conducts drafting, writing, and discussing the results of research in making this article, and providing guidance with other authors.

\section{ACKNOWLEDGMENTS}

This article is supported by Asep Andy Kurniawan, S.Pd because he has provided suggestions so that the authoress can complete this article and the committee The third Annual Civic Education Conference Universitas Pendidikan Indonesia as a reviewer for.

\section{REFERENCES}

[1] Parry, J. (2020). China coronavirus: cases surge as official admits human to human transmission. In: British Medical Journal Publishing Group.368, $\mathrm{m} 236$

[2] Strzelecki, A. (2020). Infodemiological study using google trends on coronavirus epidemic in Wuhan, China. arXiv preprint arXiv:2001.11021

[3] Dong Y, Mo X, Hu Y, et al. Epidemiology of Covid-19 Among Children in China. American Academy of Pediatrics, DOI: 10.1542/peds.20200702

[4] Kementerian Kesehatan Republik Indonesia. Info Infeksi Emerging Kementerian Kesehatan RI. 2020. https://infeksiemerging.kemkes.go.id
[5] Mulyadi, M. Partisipasi Masyarakat Dalam Penanganan Penyebaran Covid-19. Info Singkat, Pusat Penelitian Badan Keahlian DPR RI, XII(8), 13-18. 2020

[6] Amy, D.,\&Anna, C.F. Civic Engagement Scale: A Validation Study', SAGE Open, 1-7. 2013

[7] Cholisin. Ilmu Kewarganegaraan. Yogyakarta: Ombak. 2013

[8] Adler, R.P., \& Goggin, J. What Do We Mean By "Civic Engagement"?. Journal of Transformative Education, 236-253. 2005

[9] UU No. 40 Tahun 2009 Tentang Kepemudaan

[10] Wuryan \& Syaifullah. Ilmu Kewarganegaraan (civics). Laboratorium Pendidikan Kewarganegaraan: Bandung. 2008

[11] Ganeswara, GM dan Wilodati. Panduan Kuliah Pendidikan Kewarganegaraan Untuk Perguruan Tinggi. Bandung: Maulana Media Garfika. 2011

[12] Winataputra, U.S., \& Budimansyah, D. Civic Education. Konteks, landasan bahan Ajar dan Kultur Kelas. Bandung: Universitas Pendidikan Indonesia. 2007

[13] Somantri, Numan. Menggagas Pembaharuan Pendidikan IPS. Bandung: PT Remaja Rosdakarya. 2001

[14] Anggraeni, L. Transformasi Nilai Kesukarelaan sebagai Basis Political Engagement melalui Service Learning Di Universitas Pendidikan Indonesia. (Disertasi). Sekolah Pascasarjana, Universitas Pendidikan Indonesia. 2016

[15] Jacoby, B. (2019). Educating Students for Civic Engagement: What the Arts Have to Do With It. 2019. DOI: $10.1080 / 2194587 X 2019.1669467$

[16] Wahab, A \& Sapriya. Teori dan Landasan Pendidikan Kewarganegaraan. Bandung: Alfabeta. 2011

[17] Hoskins, B.L \& Mascherini, M. Measuring Active Citizenship through the Development of a Composite Indicator. Social Indicators Research, 10, 2006

[18] J.W. Creswell, Educational Research: Planning, Conducting, and Evaluating Quantitative and Qualitative Research, USA: PErson Education International

[19] Wibowo. Manajemen Perubahan (3rd ed.). PT Raja Grafindo Persada. 2016

[20] Mahardhani, Ardhana J. (2020). Menjadi Warga Negara yang Baik pada Masa Pandemi Covid-19: Persprektif Kenormalan Baru. Jurnal Pancasila dan Kewarganegaraan. Vol. 5 No. 2, 2020. DOI: 10.24269/jpk.v5.n2.2020 .pp65-76 
[21] Gunawan, I. The Function of Implementation of Social Control to Boarding Houses in Simpang Baru Tampan, Pekanbaru. JOM, Jurnal Online Mahasiswa Bidang Ilmu Sosial Dan Ilmu Politik, 4(2), $\quad 3 . \quad 2017$. https://media.neliti.com/media/publication s/134406-ID-fungsi-pelaksanaan-kontrolsosialterhad.pdf
[22] Sitohang, Marya Y,, Angga Sisca, R ., Puguh Prasetyoputra. Inisiatif Masyarakat Indonesia di masa awal pandemi covid-19: sebuah upaya pembangunan kesehatan. Jurnal Kependudukan Indonesia. 2020, 33-38 